\title{
Article
}

\section{New species and records of Bipolaris and Curvularia from Thailand}

\author{
Marin-Felix $\mathbf{Y}^{1,2^{*}}$, Senwanna $\mathbf{C}^{3}$, Cheewangkoon $\mathbf{R}^{3^{*}}$ and Crous $\mathbf{P W}^{1,2,3}$ \\ ${ }^{1}$ Westerdijk Fungal Biodiversity Institute, Uppsalalaan 8, 3584 CT Utrecht, The Netherlands \\ ${ }^{2}$ Department of Microbiology and Plant Pathology, Forestry and Agricultural Biotechnology Institute (FABI), \\ University of Pretoria, Pretoria, South Africa \\ ${ }^{3}$ Department of Plant Pathology, Faculty of Agriculture, Chiang Mai University, Chiang Mai 50200, Thailand
}

Marin-Felix Y, Senwanna C, Cheewangkoon R, Crous PW 2017 - New species and records of Bipolaris and Curvularia from Thailand. Mycosphere 8(9), 1556-1574, Doi 10.5943/mycosphere/8/9/11

\begin{abstract}
Several Bipolaris and Curvularia spp. were collected from different disease symptoms of Poaceae in Thailand. Phylogenetic analyses based on DNA sequence data of the internal transcribed spacer region and intervening 5.8S nrRNA gene, and partial fragments of the glyceraldehyde-3-phosphate dehydrogenase and the translation elongation factor 1- $\alpha$ genes, demonstrated that these isolates represent one new species of Bipolaris, B. brachiariae, and five new species of Curvularia, i.e. C. chiangmaiensis, C. dactyloctenicola, C. nodosa, $C$. pseudobrachyspora, and C. variabilis. Bipolaris brachiariae is related to B. heliconiae, $B$. maydis, and $B$. saccharicola, but produces shorter conidiophores and conidia. Curvularia chiangmaiensis is characterized by very long conidiophores to $2 \mathrm{~mm}$. Curvularia dactyloctenicola is closely related to $C$. chiangmaiensis, but can easily be distinguished by the size of its conidiophores and conidia. Curvularia nodosa is related to $C$. hawaiiensis and $C$. dactyloctenii, but it produces abundantly knotted hyphae, which were not observed in the other two species, as well as shorter conidia with fewer septa. Curvularia pseudobrachyspora is related to $C$. brachyspora, but differs in the size of its conidiophores. Finally, Curvularia variabilis can be easily distinguished by its highly variable conidia. Furthermore, the description of $B$. oryzae is emended to include two isolates belonging to this species from Thailand that produce much longer conidiophores and conidia with fewer septa than observed in previous descriptions. The present study is also the first report of Bipolaris bicolor, B. setariae and $B$. yamadae from Thailand. Moreover, new hosts are reported for B. bicolor (Eleusine indica), B. setariae (Imperata cylindrica), and Curvularia verruculosa (Eleusine indica).
\end{abstract}

Key words - six new species - multigene phylogeny - phytopathogenic fungi - Poaceae systematics 


\section{Introduction}

Bipolaris and Curvularia include phytopathogenic species with a worldwide distribution and wide host range, particularly cereals and grasses (Poaceae) (Ellis 1971, Sivanesan 1987, Manamgoda et al. 2014, Tan et al. 2016). Some species have caused devastating diseases on staple food crops, such as barley, maize, rice, sorghum and wheat that resulted in significant yield losses. Examples of these devastating epidemics are the Bipolaris maydis disease outbreak in maize crops in the UK and USA in the 1970s (Ullstrup 1972) and the Curvularia leaf spot of maize caused by Curvularia lunata (Li et al. 2006). A third example is the Bengal famine in India (1943-1944), which was linked to rice disease caused by Bipolaris oryzae (Ou 1985, Scheffer 1997).

Despite of their importance, species delimitation in Bipolaris and Curvularia remains problematic due to the overlapping morphological characters among many species (Manamgoda et al. 2014, 2015). Even the distinction between these two genera is difficult, since they are morphologically similar (Sivanesan 1987, Manamgoda et al. 2015). Curvularia is characterized by conidia with inordinately enlarged intermediate cells, which contributes to its characteristic curvature, while in Bipolaris the curvature is continuous throughout the length of the conidium. Furthermore, conidia in Bipolaris are usually longer than those of Curvularia. In order to achieve proper generic and species delimitation, phylogenetic studies using the internal transcribed spacer region and intervening 5.8S nrRNA gene (ITS), and partial fragments of the glyceraldehyde-3-phosphate dehydrogenase (gapdh) and the translation elongation factor 1- $\alpha$ genes (tef1) were recently performed (Manamgoda et al. 2012, 2014, 2015, Tan et al. 2016). Phylogenetic studies based on these loci made it possible to reallocate species of Cochliobolus (sexual morph) to either Bipolaris or Curvularia (Manamgoda et al. 2012).

Hitherto there are 40 accepted species included in Bipolaris, and 74 in Curvularia (MarinFelix et al. 2017). Several species of both genera were reported previously from Thailand (Farr \& Rossman 2017). However, only a few records have thus far been corroborated based on molecular data, namely Bipolaris coffeana, B. oryzae, Curvularia alcornii, C. asianensis, $C$. borreriae, C. hawaiiensis, $C$. hominis, $C$. lunata, and $C$. verruculosa. Taking into consideration the difficulty of delimiting species of both genera based only on morphology, the incidence of the other species in Thailand remains to be confirmed. This is complicated, however, by the fact that very few cultures linked to the various reports are presently available for study. Therefore, it is of crucial importance to recollect specimens of both genera, and verify their hosts and distribution.

The main objective of the present study was to confirm the identity of different Bipolaris and Curvularia species associated with plant disease symptoms of selected members of Poaceae in Thailand, and to resolve their taxonomy and DNA phylogeny.

\section{Materials \& Methods Isolates}

Different members of Poaceae displaying leaf spots were collected in fields in Thailand, mainly in the province of Chiang Mai, but also from Lampang, and taken to the laboratory for fungal isolation. Specimens were initially incubated in moist chambers (Petri-dishes containing moist filter paper) to enhance sporulation. Leaves were inspected daily for microfungi, and single conidial colonies were established on $2 \%$ potato dextrose agar (PDA; recipe and methodology according to Crous et al. 2009). All isolates are maintained in the working 
collection of P.W. Crous (CPC), housed at the Westerdijk Fungal Biodiversity Institute, and dried specimens deposited in the Westerdijk Institute, Utrecht, the Netherlands (CBS) (Table 1).

\section{DNA isolation, amplification and analyses}

Fungal DNA of all isolates was extracted and purified directly from the colonies according to the Wizard® Genomic DNA purification kit protocol (Promega, Madison, USA). The internal transcribed spacer region of the nuclear rDNA (ITS), and partial fragments of the glyceraldehyde-3-phosphate dehydrogenase (gapdh) and the translation elongation factor 1- $\alpha$ (tefl) genes were amplified and sequenced using the primers and protocols specified in White et al. (1990) (ITS) and Manamgoda et al. (2012) (gapdh and tef1). Two different phylogenetic studies of the combined dataset (ITS, gapdh and tefl) were carried out, the first one including the isolates belonging to Bipolaris and the second one those belonging to Curvularia, together with sequences of the type or representative strains of all the accepted species in each genus. The Maximum-Likelihood (ML) and Bayesian Inference (BI) methods were used in phylogenetic analyses as described by Hernández-Restrepo et al. (2016). Sequence data generated in this study were deposited in GenBank (GenBank accession numbers shown in Table 1), and the alignments and trees in TreeBASE (http://www.treebase.org, accession http://purl.org/phylo/treebase/phylows/study/TB2:S21204). GenBank accession numbers of the sequences retrieved from GenBank are available in Marin-Felix et al. (2017).

\section{Morphology}

Vegetative and reproductive structures were mounted in clear lactic acid from colonies sporulating on PDA and synthetic nutrient-poor agar (SNA) supplemented with autoclaved banana leaves under near-ultraviolet light (12 h light, $12 \mathrm{~h}$ dark) at $25^{\circ} \mathrm{C}$ (Crous et al. 2009). Photomicrographs were made with Nikon Eclipse Ni microscope, using a DS-Ri2 digital camera (Nikon, Tokyo, Japan) and NIS-Elements imaging software v. 4.20. At least 30 measurements were taken of structures for the description of morphological features. For cultural characterisation, isolates were grown and incubated on PDA at $25{ }^{\circ} \mathrm{C}$ for $1 \mathrm{wk}$ in the dark. Colour notations were rated according to the colour charts of Rayner (1970). Taxonomic novelties are deposited in MycoBank (www.MycoBank.org; Crous et al. 2004).

\section{Results}

\section{Phylogenetic analyses}

To maximize the quality of the alignment, two different alignments were performed. The first one included the isolates belonging to Bipolaris and ex-type or representative strains of all the accepted species in that genus. The lengths of the fragments of the three genes used in the combined dataset were 479 bp (ITS), 472 bp (gapdh) and 892 bp (tefl). The length of the final alignment was $1843 \mathrm{bp}$. The second alignment included the isolates of Curvularia and ex-type or representative strains of all the accepted species in that genus. The lengths of the fragments of the three genes used in the combined dataset were 504 bp (ITS), 461 bp (gapdh) and 893 bp (tefl), resulting in a final alignment of $1858 \mathrm{bp}$.

Figure 1 shows the tree inferred from a RAxML analysis of the combined dataset of the taxa belonging to Bipolaris. Our isolates were located in six different well-supported subclades. The isolates CPC 28811 and CPC 28825 clustered with B. bicolor, and CPC 28823 with $B$. maydis. Isolate CPC 28802 was located in a subclade together with B. setariae, and CPC 28807 
Table 1 Collection details and accession numbers of Bipolaris and Curvularia spp. from Thailand studied.

\begin{tabular}{|c|c|c|c|c|c|c|}
\hline \multirow[t]{2}{*}{ Species } & \multirow[t]{2}{*}{ Isolates $^{1}$} & \multirow[t]{2}{*}{ Host } & \multirow[t]{2}{*}{ Region } & \multicolumn{3}{|c|}{ GenBank accession numbers $^{2}$} \\
\hline & & & & ITS & gpdah & tef1 \\
\hline \multirow[t]{2}{*}{ Bipolaris bicolor } & CPC 28811 & Eleusine indica & Maetaeng, Chiang Mai & MF490804 & MF490826 & MF490848 \\
\hline & CPC 28825 & Unknown & Nong Hoi Royal project, Chiang Mai & MF490805 & MF490827 & MF490849 \\
\hline \multirow[t]{2}{*}{ Bipolaris brachiariae } & CPC $28819^{\mathrm{T}}$ & Brachiaria mutica & $\begin{array}{l}\text { Mae Hia Agricultural Research, Demonstrative } \\
\text { and Training Center, Chiang Mai }\end{array}$ & MF490806 & MF490828 & MF490850 \\
\hline & CPC 28820 & Unknown & $\begin{array}{l}\text { Mae Hia Agricultural Research, Demonstrative } \\
\text { and Training Center, Chiang Mai }\end{array}$ & MF490807 & MF490829 & MF490851 \\
\hline Bipolaris maydis & CPC 28823 & Zea mays & $\begin{array}{l}\text { Mae Hia Agricultural Research, Demonstrative } \\
\text { and Training Center, Chiang Mai }\end{array}$ & MF490808 & MF490830 & MF490852 \\
\hline \multirow[t]{2}{*}{ Bipolaris oryzae } & CPC 28826 & Oryza sativa & Sanpatong, Chiang Mai & MF490809 & MF490831 & MF490853 \\
\hline & СРC 28828 & Oryza sativa & $\begin{array}{l}\text { Mae Hia Agricultural Research, Demonstrative } \\
\text { and Training Center, Chiang Mai }\end{array}$ & MF490810 & MF490832 & MF490854 \\
\hline Bipolaris setariae & CPC 28802 & Imperata cylindrica & Chiang Mai university, Chiang Mai & MF490811 & MF490833 & - \\
\hline Bipolaris sorokiniana & CPC 28832 & Triticum aestivum & Khunwang Royal project, Chiang Mai & MF490812 & MF490834 & MF490855 \\
\hline Bipolaris yamadae & CPC 28807 & Unknown & Jom Thong, Chiang Mai & MF490813 & MF490835 & MF490856 \\
\hline Curvularia chiangmaiensis & CPC $28829^{\mathrm{T}}$ & Zea mays & Khunwang Royal project, Chiang Mai & MF490814 & MF490836 & MF490857 \\
\hline Curvularia dactyloctenicola & CPC $28810^{\mathrm{T}}$ & Dactyloctenium aegyptium & Doi Saket, Chiang Mai & MF490815 & MF490837 & MF490858 \\
\hline \multirow[t]{3}{*}{ Curvularia nodosa } & СРC 28801 & Brachiaria reptans & Sansai, Chiang Mai & MF490817 & MF490839 & MF490860 \\
\hline & CPC 28812 & Chloris barbata & Sankamphaeng, Chiang Mai & MF490818 & MF490840 & MF490861 \\
\hline & CPC $28800^{\mathrm{T}}$ & Digitaria ciliaris & Maewang, Chiang Mai & MF490816 & MF490838 & MF490859 \\
\hline Curvularia pseudobrachyspora & CPC $28808^{\mathrm{T}}$ & Eleusine indica & Jom Thong, Chiang Mai & MF490819 & MF490841 & MF490862 \\
\hline \multirow[t]{4}{*}{ Curvularia variabilis } & CPC $28815^{\mathrm{T}}$ & Chloris barbata & Samoeng, Chiang Mai & MF490822 & MF490844 & MF490865 \\
\hline & CPC 28813 & Digitaria ciliaris & Doi Saket, Chiang Mai & MF490820 & MF490842 & MF490863 \\
\hline & СРC 28814 & Digitaria ciliaris & Chiang Mai university, Chiang Mai & MF490821 & MF490843 & MF490864 \\
\hline & CPC 28816 & Imperata cylindrica & Samoeng, Chiang Mai & MF490823 & MF490845 & MF490866 \\
\hline \multirow[t]{2}{*}{ Curvularia verruculosa } & CPC 28792 & Cynodon dactylon & EGTA Golf course, Mae Moh, Lampang & MF490825 & MF490847 & MF490868 \\
\hline & CPC 28809 & Eleusine indica & Mae-Klang Waterfall, Jom Thong, Chiang Mai & MF490824 & MF490846 & MF490867 \\
\hline
\end{tabular}

${ }^{1}$ CPC: working collection of P.W. Crous, housed at the Westerdijk Fungal Biodiversity Institute, Utrecht, the Netherlands. ${ }^{\mathrm{T}}$ indicates ex-type strains.

${ }^{2}$ ITS: internal transcribed spacers and intervening 5.8S nrDNA; gapdh: partial glyceraldehyde-3-phosphate dehydrogenase gene; tef1: partial translation elongation factor 1-alpha gene 


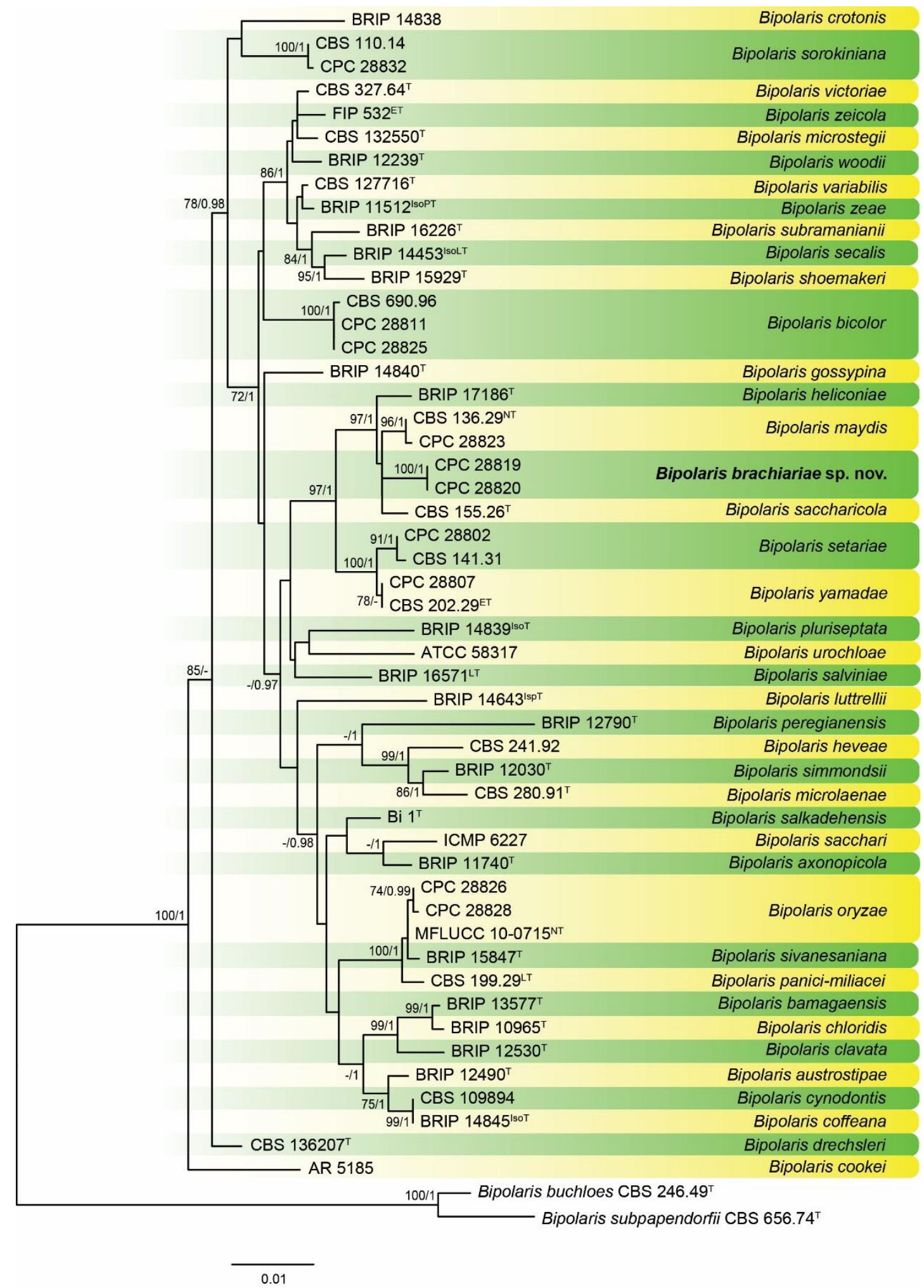

Figure 1 - RAxML phylogram obtained from the combined ITS, gapdh and tefl sequences of all the accepted species of Bipolaris and the isolates from Thailand belonging to this genus. The tree was rooted to Curvularia buchloës CBS 246.49 and Curvularia subpapendorfii CBS 656.74. The novel species described in this study is shown in bold. RAxML bootstrap support (BS) values 
above $70 \%$ and Bayesian posterior probability scores above 0.95 are shown at the nodes. GenBank accession numbers are indicated in Table 2. T, ET, IsoT, IsoLT, IsoPT, LT and ${ }^{\mathrm{NT}}$ indicate extype, ex-epitype, ex-isotype, ex-isolectotype, ex-isoparatype, ex-lectotype and ex-neotype strains, respectively.

with B. yamadae. The isolates CPC 28826 and CPC 28828 were located in a well-supported clade [74 \% RAxML bootstrap support values (BS) / 0.99 Bayesian posterior probabilities (PP)] closely related to the ex-neotype strain of $\mathrm{B}$. oryzae, differing only in 1 nucleotide. Morphologically, both strains are similar to B. oryzae but these differ in the size of the conidiophores and conidial septation. Finally, the isolates CPC 28819 and CPC 28820 were located in a well-supported clade (100\% BS / $1 \mathrm{PP})$ related to B. heliconiae, B. maydis, and B. saccharicola. Morphologically, our isolates produce shorter conidiophores and conidia than the other three species.

Figure 2 represents the RAxML tree derived from the combined dataset of the taxa belonging to Curvularia. Two of the isolates were located in a well-supported subclade (100\% BS / 1 PP) together with $C$. verruculosa. The other isolates were located in different clades independent to the other accepted species of Curvularia, representing new species in that genus. Isolate CPC 28808 was related to $C$. brachyspora but these can be distinguished by the size of the conidiophores, and the distribution and the host where these are found. Isolates CPC 28800, CPC 28801 and CPC 28812 formed a well-supported subclade (100\% BS / 1 PP) related to $C$. hawaiiensis and $C$. dactyloctenii. Morphologically, our isolates differ in the production of hyphae that appeared to have knots, and shorter and less septate conidia. The isolates CPC 28813, CPC 28814, CPC 28815 and CPC 28816 were located in a well-supported subclade (100 $\%$ BS / 1 PP) apart from the other Curvularia spp. All of these isolates are characterised by the production of conidia very variable in size. Finally, the isolates CPC 28810 and CPC 28829 were located in two different clades related to $C$. lunata and $C$. sorghina, differing from these two species and each other in the size of the conidiophores and conidia, as well as septation.

Based on the molecular and morphological results, we propose the introduction of one new species of Bipolaris and five new species of Curvularia. Moreover, the description of B. oryzae is emended in order to include the morphological differences observed in the isolates from Thailand.

\section{Taxonomy}

Bipolaris brachiariae Y. Marín, Senwanna \& Crous, sp. nov.

Figs 3, 10A

MycoBank: MB822081

Etymology - Name refers to the host genus this fungus was first isolated from, Brachiaria.

Leaf spots ellipsoid, up to $5 \mathrm{~mm}$ long, grey to pale brown at the middle, dark brown at the edge. Asexual morphology on PDA: Hyphae hyaline to pale brown, branched, septate. Conidiophores arising singly or in groups, septate, straight or flexuous at the apex, sometimes geniculate at upper part, cells walls thicker than those of vegetative hyphae, mononematous, macronematous, pale brown to brown, lighter towards apex, 105-195 $\times 2.5-5 \mu \mathrm{m}$. Conidiogenous cells verruculose, terminal or intercalary, proliferating sympodially, pale brown to brown, subcylindrical to slightly swollen, 10-20 × 4-7 $\mu \mathrm{m}$. Conidia slightly verruculose, curved, ellipsoidal to obovoid, pale brown to brown, 4-10-distoseptate, (17.5-)20-87.5(-97.5) $\times$ (10-)12.5-17.5 $\mu \mathrm{m}$; hila protruding, darkened, thickened. 


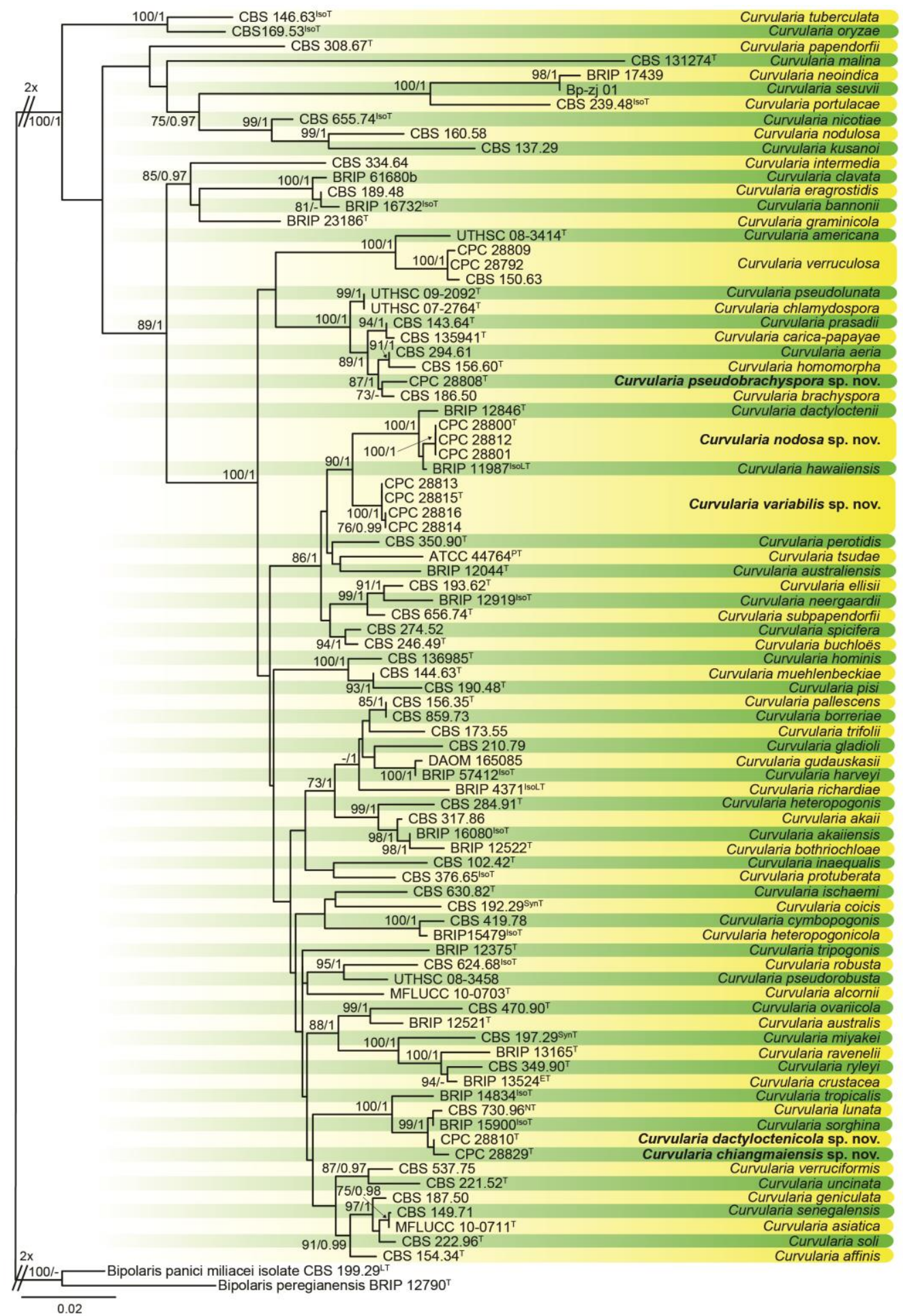

Figure 2 - RAxML phylogram obtained from the combined ITS, gapdh and tefl, sequences of all the accepted species of Curvularia and the isolates from Thailand belonging to this genus. The tree was rooted to Bipolaris panici-miliacei CBS 199.29 and Bipolaris peregianensis BRIP 12790. The novel species described in this study are shown in bold. RAxML bootstrap support (BS) values above $70 \%$ and Bayesian posterior probability scores above 0.95 are shown at the 


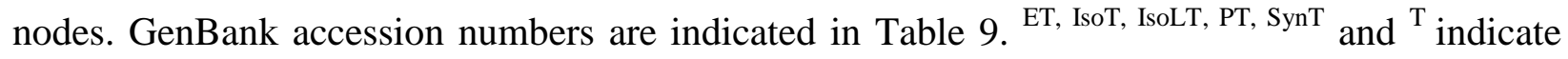
ex-epitype, ex-isotype, ex-isolectotype, ex-paratype, ex-syntype and ex-type strains, respectively.

Cultural characteristics - Colonies on PDA reaching $90 \mathrm{~mm}$ diam in $1 \mathrm{wk}$, with sparse aerial mycelium; surface olivaceous with margins buff; reverse olivaceous with margins buff and centre fuscous black.

Host - Brachiaria mutica.

Distribution - Thailand.

Material examined - THAILAND, Chiang Mai, Mae Hia Agricultural Research, Demonstrative and Training Center, on Brachiaria mutica, 28 August 2010, C. Senwanna (CBS H-23191, holotype; culture ex-type CPC 28819); ibid., on unknown Poaceae, culture CPC 28820.

Notes - Bipolaris brachiariae is related to B. heliconiae, B. maydis, and B. saccharicola. However, it can easily be distinguished by the size of the conidiophores (up to $195 \mu \mathrm{m}$ long in $B$. brachiaria vs. $600 \mu \mathrm{m}$ long in B. heliconiae vs. $712 \mu \mathrm{m}$ long in B. maydis vs. $900 \mu \mathrm{m}$ long in $B$. saccharicola), and conidia [(17.5-)20-87.5(-97.5) $\mu \mathrm{m}$ long in B. brachiaria vs. 65-150 $\mu \mathrm{m}$ long in B. heliconiae vs. (59-)66-102(-160) $\mu \mathrm{m}$ long in B. maydis vs. (30-)45-120 $\mu \mathrm{m}$ long in $B$. saccharicola]. Bipolaris maydis has also been reported from Thailand, but not from Brachiaria mutica.

Bipolaris oryzae (Breda de Haan) Shoemaker, Canad. J. Bot. 37: 883. $1959 . \quad$ Figs 4, 10B Basionym: Helminthosporium oryzae Breda de Haan, Bulletin Inst. Bot. Buitenzorg 6: 11. 1900. Synonyms: Drechslera oryzae (Breda de Haan) Subram. \& B.L. Jain, Curr. Sci. 35: 354. 1966. Luttrellia oryzae (Breda de Haan) Gornostaĭ (as "Lutrellia"), in Azbukina et al. (eds), Vodorosli, Griby i Mkhi Dal'nego Vostoka (Algae, Fungi and Mosses of the Soviet Far-East) (Vladivostok): 81. 1978.

Ophiobolus miyabeanus S. Ito \& Kurib., Ann. Phytopathol. Soc. Japan 2: 1. 1927 (fide Ito \& Kuribayashi 1927).

Cochliobolus miyabeanus (S. Ito \& Kurib.) Drechsler ex Dastur, Indian J. Agric. Sci. 12: 733. 1942 (fide Sivanesan 1987).

Helminthosporium zizaniae Y. Nisik., Rep. Ohara Inst. Agric. Res. 4: 122. 1929.

Bipolaris zizaniae (Y. Nisik.) Shoemaker, Canad. J. Bot. 37: 885. 1959.

Drechslera zizaniae (Y. Nisik.) Subram. \& B.L. Jain, Curr. Sci. 35: 355. 1966.

Helminthosporium oryzae Miyabe \& Hori, Rept. Imp. Centr. Agric. Exp. Stn. Nishigohara, Japan 18: 79. 1901 (fide Sivanesan 1987).

Leaf spots oval or ovoid, brown, sometimes purplish, with red brown to dark brown border and white to grey or grey to pale brown centre, often surrounded by yellow halo. Asexual morphology on PDA: Hyphae hyaline to pale brown, branched, septate, 2-5(-6) $\mu \mathrm{m}$. Conidiophores arising singly or in groups, septate, straight or flexuous, sometimes geniculate in the upper part, size of cells not decreasing towards apex, sometimes branched, cells walls thicker than those of vegetative hyphae, mononematous, semi- to macronematous, pale brown to brown to black, paler towards apex, sometimes swollen at the base, up to $1200 \mu \mathrm{m}$ tall. Conidiogenous cells smooth-walled to verruculose, terminal or intercalary, proliferating sympodially, pale 


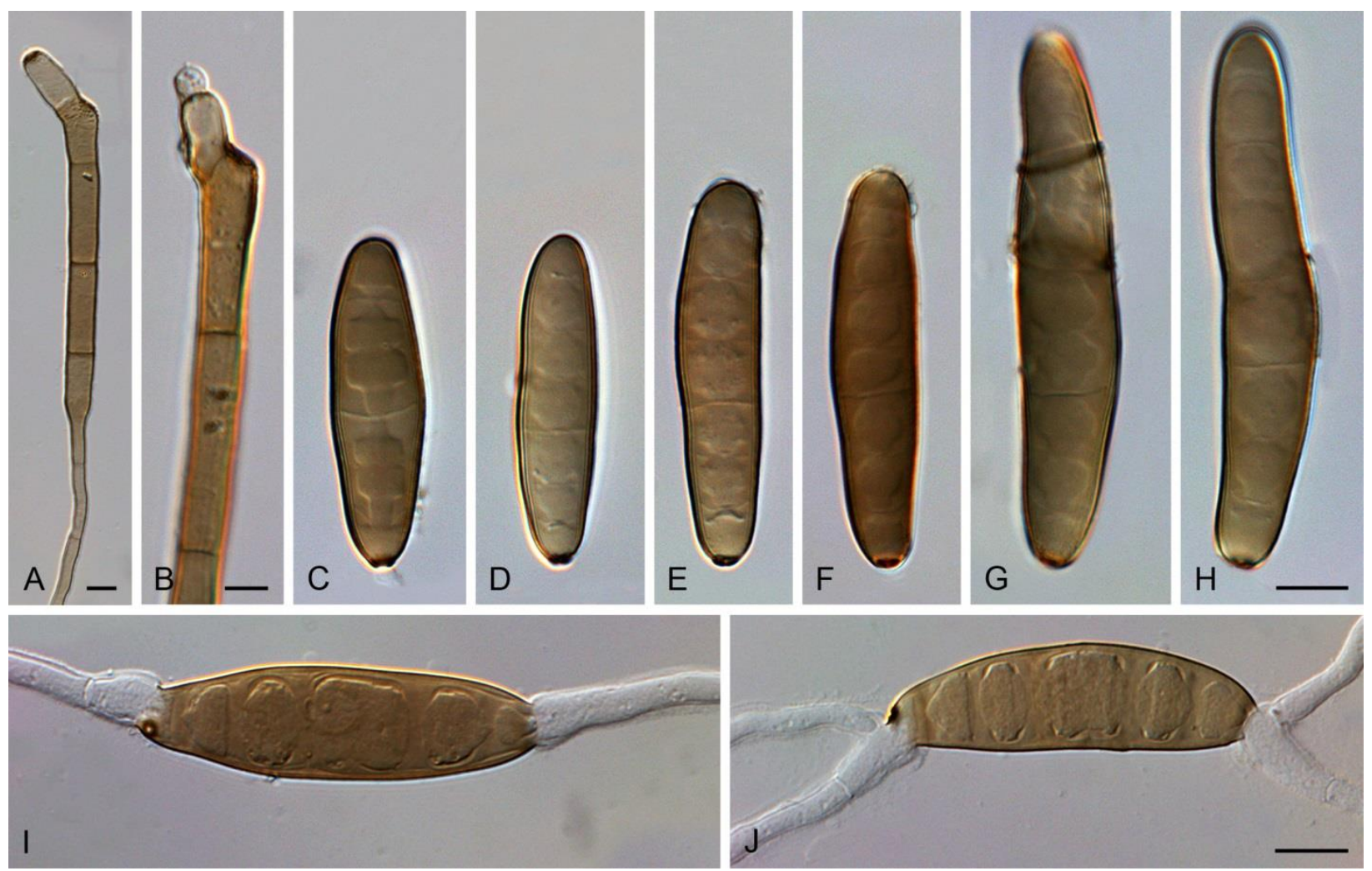

Figure 3 - Bipolaris brachiariae $\left(\right.$ CPC $\left.28819^{\mathrm{T}}\right)$. A, B. Conidiophores. C-H. Conidia. I, J. Germinating conidia. Scale bars: A, B $=5 \mu \mathrm{m}$; $\mathrm{H}$ applies to $\mathrm{C}-\mathrm{H}$, J applies to I, $\mathrm{J}=5 \mu \mathrm{m}$.

brown to brown, subcylindrical to slightly swollen, (11-) 13-23(-25.5) $\times 5-8 \mu \mathrm{m}$. Conidia smooth-walled, mostly curved, navicular, fusiform, obclavate or cylindrical, pale brown to brown, apical and basal cells sometimes slightly paler than the middle cells, (4-)6-10(-12)distoseptate, (55-)65-108(-155) × (10-)14-20(-22) $\mu \mathrm{m}$; hila slightly protruding, darkened, thickened, 2.5-4.5 $\mu \mathrm{m}$. Secondary sporulation in some conidia. Sexual morph see Manamgoda et al. (2014).

Cultural characteristics - Colonies on PDA reaching $90 \mathrm{~mm}$ diam in $1 \mathrm{wk}$, with abundant aerial mycelium giving a cottony appearance, fluffy; reverse olivaceous to olivaceous dark; surface smoke grey to olivaceous.

Material examined - THAILAND, Chiang Mai, San Pa Tong, on Oryza sativa, C. Senwanna, culture CPC 28826; Chiang Mai, Mae Hia Agricultural Research, Demonstrative and Training Centre, Chiang Mai University, on Oryza sativa, C. Senwanna, culture CPC 28828.

Notes - The isolates CPC 28826 and CPC 28828 were closely related to B. oryzae, differing in only 1 nucleotide in the gapdh locus. Moreover, both were isolated from Oryzae sativa, as is $B$. oryzae, which is also known from Thailand. Therefore, we consider these isolates as representative of $B$. oryzae. The description of the asexual morph of B. oryzae is emended mainly to incorporate the size of the conidiophores observed in these isolates, which reach up to $1200 \mu \mathrm{m}$, while conidiophores were reported up to $600 \mu \mathrm{m}$ tall by Sivanesan et al. (1987) and up to $650 \mu \mathrm{m}$ by Manamgoda et al. (2014). Moreover, our isolates produce mainly 6-8-distoseptate conidia, while in the ex-neotype strain they are mainly 10-distoseptate (Manamgoda et al. 2014). 

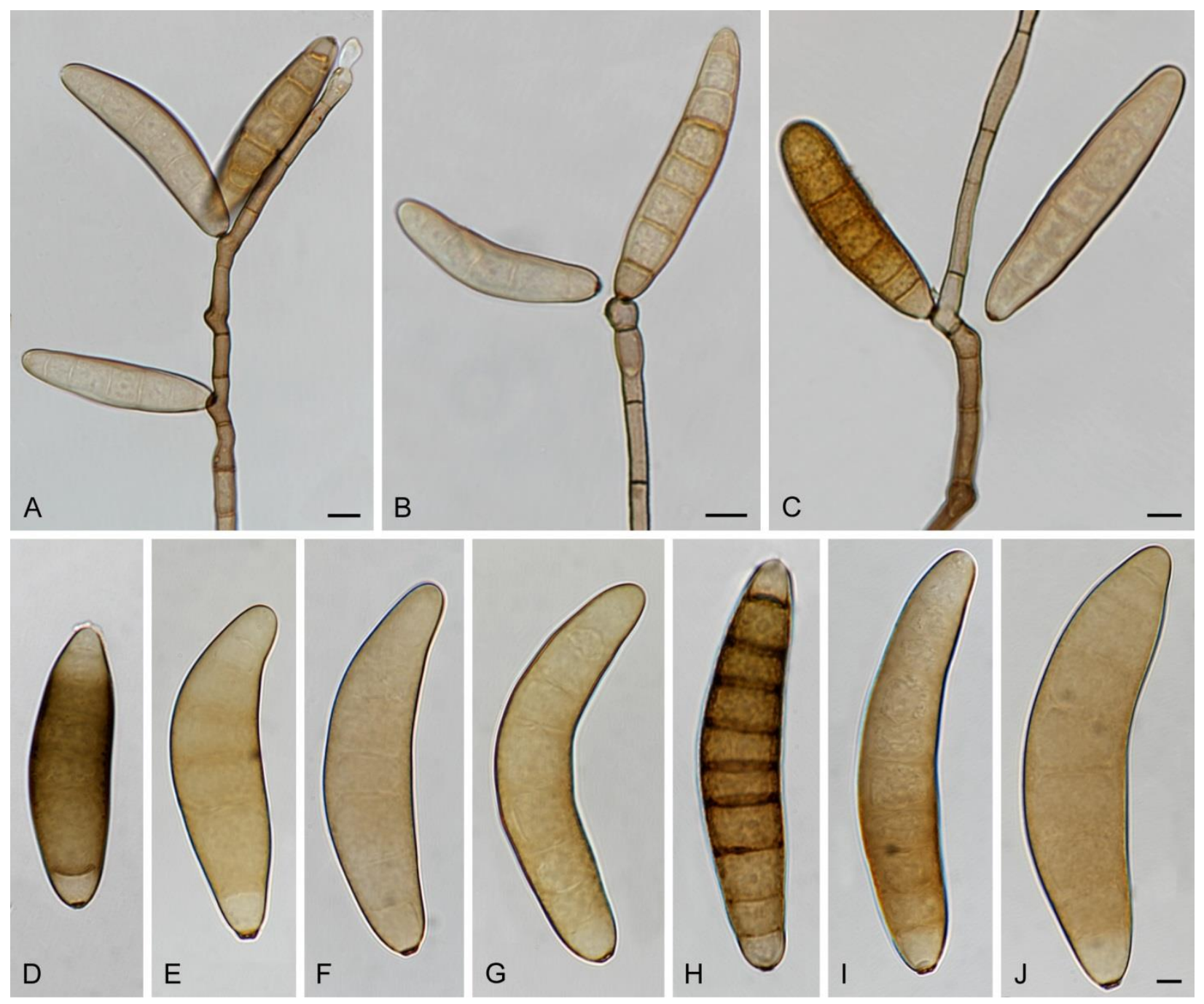

Figure 4 - Bipolaris oryzae (CPC 28826). A-C. Conidiophores and conidia. D-J. Conidia. Scale bars: $\mathrm{A}-\mathrm{C}=10 \mu \mathrm{m}$; J applies to $\mathrm{D}-\mathrm{J}=5 \mu \mathrm{m}$.

Curvularia chiangmaiensis Y. Marín, Senwanna \& Crous, sp. nov.

MycoBank: MB822082

Etymology - Named for the region where it was isolated from, Chiang Mai.

Leaf spots oval, red-brown ellipse with tan centre, surrounded by yellow halo. Asexual morphology on PDA: Hyphae hyaline to pale brown, branched, septate, 2-4 $\mu \mathrm{m}$ diam. Conidiophores arising singly or in groups, septate, straight or flexuous, sometimes geniculate in the upper part, size of cells not decreasing towards apex, sometimes branched, cells walls thicker than those of vegetative hyphae, mononematous, semi- to macronematous, pale brown to brown, paler towards apex, sometimes swollen at the base, up to $2000 \mu \mathrm{m}$ tall. Conidiogenous cells smooth-walled to slightly verruculose, terminal or intercalary, proliferating sympodially, pale brown to brown, subcylindrical to swollen, (4.5-) 6.5-15(-17) $\times 4-6 \mu \mathrm{m}$. Conidia slightly verruculose, curved, middle cells unequally enlarged, ellipsoidal to obovoid, pale brown to brown, apical and basal cells slightly paler than the middle cells, (2-)3-distoseptate, 

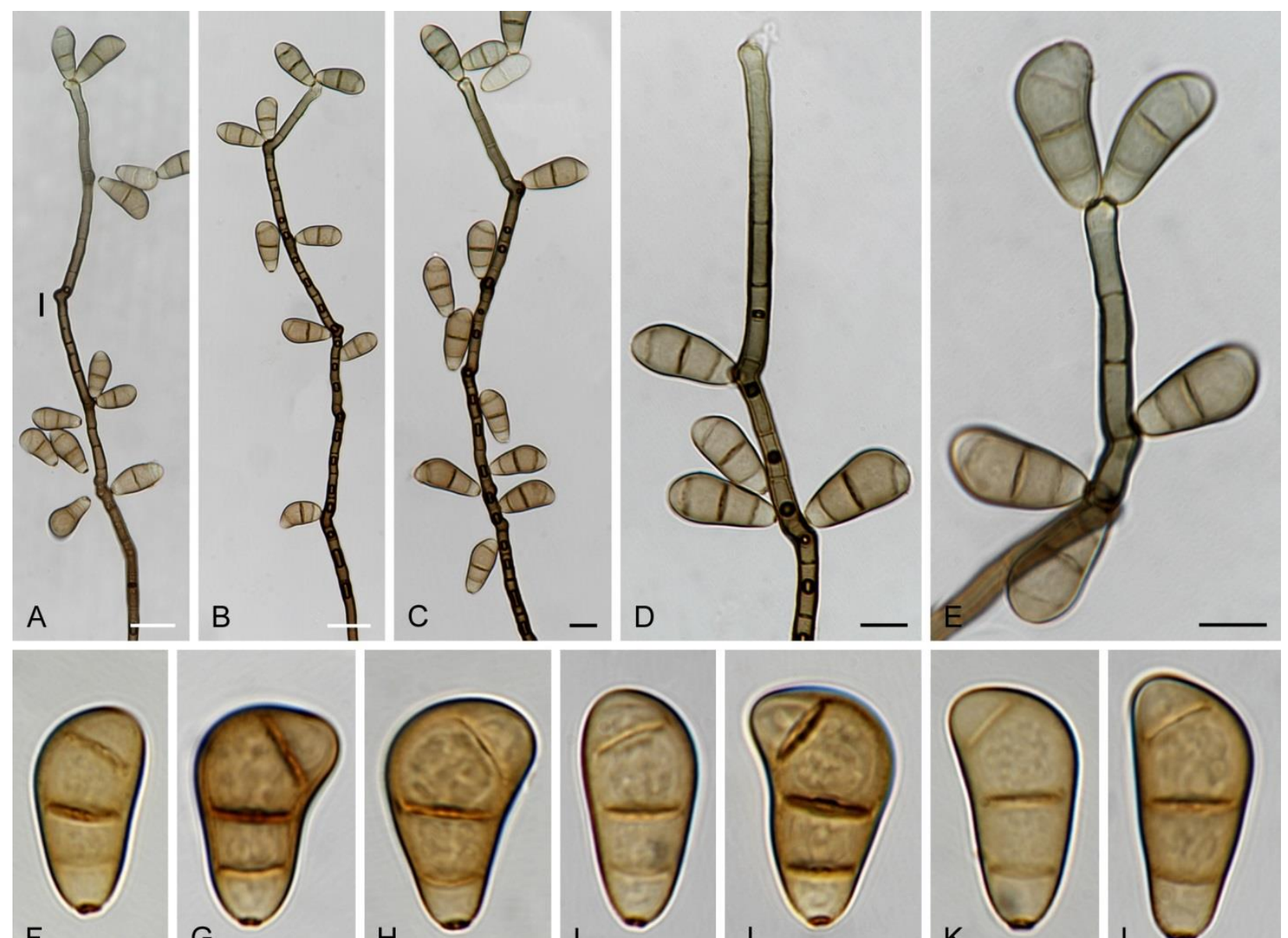

$\mathrm{F}$
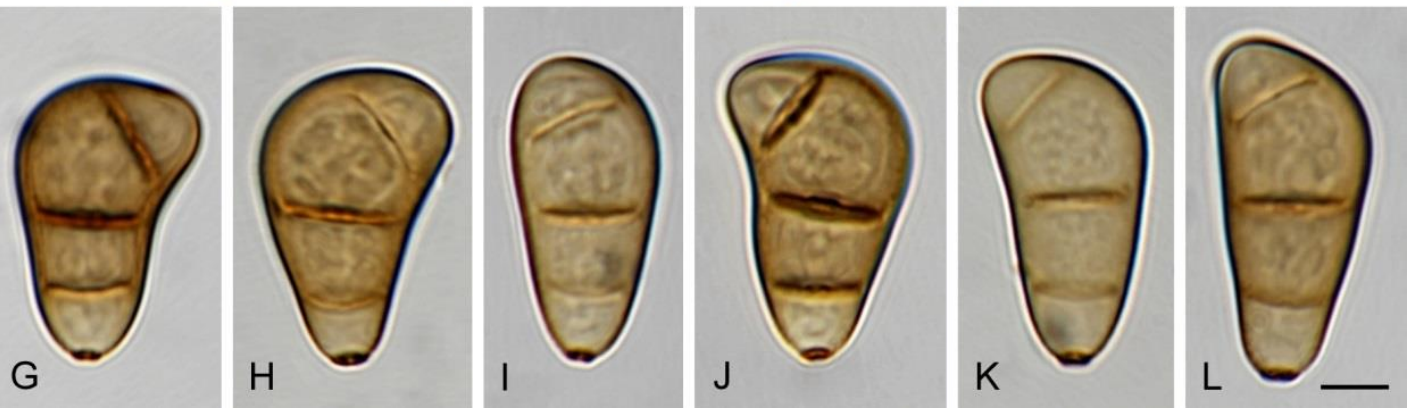

Figure 5 - Curvularia chiangmaiensis $\left(\right.$ CPC $\left.28829^{\mathrm{T}}\right)$. A-E. Conidiophores and conidia. F-L. Conidia. Scale bars: A, B $=20 \mu \mathrm{m} ; \mathrm{D}, \mathrm{E}=10 \mu \mathrm{m} ; \mathrm{L}$ applies to $\mathrm{F}-\mathrm{L}=5 \mu \mathrm{m}$.

17-23.5(-25.5) × 9-12.5 $\mu \mathrm{m}$; hila protruding, darkened, thickened, 2-3.5 $\mu \mathrm{m}$. Microconidiation, chlamydospores and sexual morph not observed.

Cultural characteristics - Colonies on PDA reaching 65-70 mm diam in $1 \mathrm{wk}$, with sparse aerial mycelium, margins slightly lobate; surface chestnut with margins umber; reverse honey to isabelline to sepia.

Host - Zea mays.

Distribution - Thailand.

Material examined - THAILAND, Chiang Mai, Jom Thong, on Zea mays, 23 May 2010, C. Senwanna (CBS H-23192, holotype; culture ex-type CPC 28829).

Notes - Curvularia chiangmaiensis is related to C. lunata, C. sorghina and the new species described below, $C$. dactyloctenicola. Morphologically, these species are similar producing very long conidiophores, although shorter than those of $C$. chiangmaiensis. Curvularia sorghina differs from $C$. chiangmaiensis, $C$. dactyloctenicola and $C$. lunata in its conidial septation, being 2-6-distoseptate while the other three species are 3-distoseptate.

Curvularia chiangmaiensis and C. lunata have been isolated in Thailand and occur on Zea mays. However, both can be easily distinguished based on their conidiophore dimensions (up to $2000 \mu \mathrm{m}$ in C. chiangmaiensis vs. up to $650 \mu \mathrm{m}$ in C. lunata). Curvularia lunata is a unique 
species in this complex, producing a sexual morph. The differences with $C$. dactyloctenicola are discussed in the notes below.

Curvularia dactyloctenicola Y. Marín, Senwanna \& Crous, sp. nov.

Figs 6, 10D MycoBank: MB822083

Etymology - Name refers to the host genus that this fungus was isolated from, Dactyloctenium.

Leaf spots oval or fusiform, first brown-red, then brown, often surrounded by yellow halo. Asexual morphology on SNA with autoclaved banana leaves: Hyphae hyaline to subhyaline, branched, septate, 2-4 $\mu \mathrm{m}$ diam. Conidiophores arising in groups, septate, straight or flexuous, sometimes geniculate in the upper part, size of cells not decreasing towards apex, sometimes branched, cells walls thicker than those of vegetative hyphae, mononematous, semi- to macronematous, pale brown, paler towards apex, not swollen at the base, 50-300 $(-400) \times 3-5.5$ $\mu \mathrm{m}$. Conidiogenous cells smooth-walled, terminal or intercalary, proliferating sympodially, pale brown, subcylindrical to swollen, (3.5-) 6-16.5 × 3.5-5.5 $\mu \mathrm{m}$. Conidia smooth-walled to slightly verruculose, mostly curved, middle cells sometimes unequally enlarged, ellipsoidal to obovoid, pale brown, apical and basal cells slightly paler than the middle cells, 3-distoseptate, 21.5-28 $\times$ 7-9 $\mu \mathrm{m}$; hila flat to slightly protruding, darkened, thickened, 2-3 $\mu \mathrm{m}$. Microconidiation, chlamydospores and sexual morph not observed.

Cultural characteristics - Colonies on PDA reaching 55-59 $\mathrm{mm}$ diam in $1 \mathrm{wk}$, with moderate aerial mycelium giving a cottony appearance; surface mouse grey with margins luteus to umber; reverse fuscous black with margins saffron.

Host - Dactyloctenium aegyptium.

Distribution - Thailand.

Material examined - THAILAND, Chiang Mai, Doi Saket, on Dactyloctenium aegyptium, 6 June 2010, C. Senwanna (CBS H-23193, holotype; culture ex-type CPC 28810).

Notes - Curvularia dactyloctenicola is related to $C$. chiangmaiensis, $C$. lunata and $C$. sorghina. However, this species produces the shortest conidiophores of the complex (up to 400 $\mu \mathrm{m}$ tall). As mentioned above, $C$. sorghina can be distinguished by the production of 2-6distoseptate conidia. Curvularia chiangmaiensis and $C$. lunata are also isolated from Thailand, but only $C$. lunata was isolated from the same host, Dactyloctenium aegyptium. Apart from the conidiophore size (up to $650 \mu \mathrm{m}$ in $C$. lunata vs. up to $400 \mu \mathrm{m}$ in $C$. dactyloctenicola), both species can be distinguished by the size of their conidia, being much wider in C. lunata (9-15 $\mu \mathrm{m}$ in $C$. lunata vs. 7-9 $\mu \mathrm{m}$ in $C$. dactyloctenicola). Curvularia chiangmaiensis also produces longer conidiophores (up to $2000 \mu \mathrm{m}$ ) and wider conidia $(9-12.5 \mu \mathrm{m}$ diam) than $C$. dactyloctenicola.

Curvularia nodosa Y. Marín, Cheew. \& Crous, sp. nov.

Figs 7, 10E MycoBank: MB822084 hyphae.

Etymology - From Latin nodosa, knotty, referring to the abundant presence of knotted

Leaf spots small, brown to dark brown or black. Asexual morphology on PDA: Hyphae hyaline to pale brown, branched, septate, frequently swollen and constricted at the septa giving a knotted appearance, 2-7 $\mu \mathrm{m}$ diam. Conidiophores arising singly or in groups, septate, straight or flexuous, sometimes geniculate in the upper part, size of cells do not decrease towards apex, 

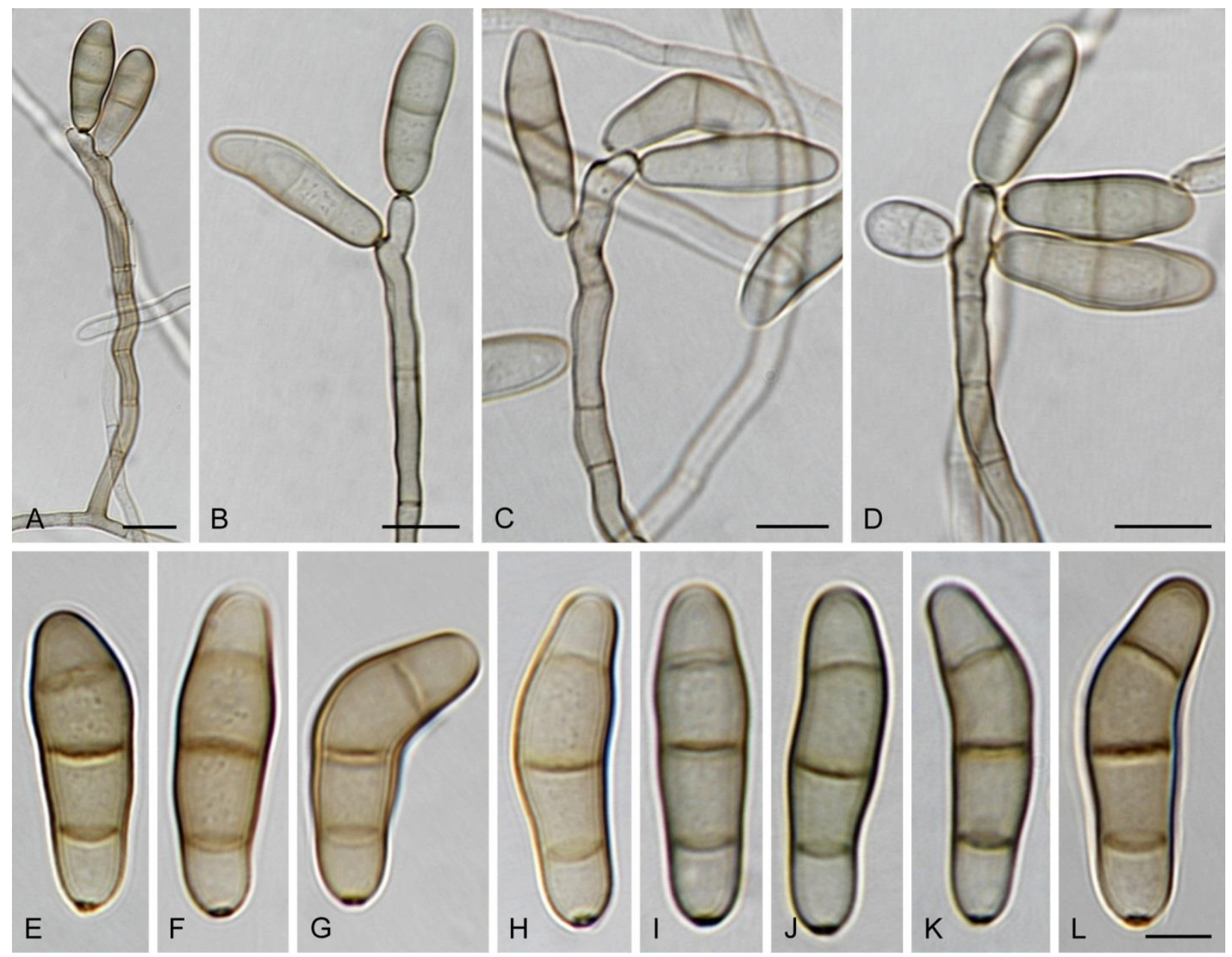

Figure 6 - Curvularia dactyloctenicola $\left(\mathrm{CPC} 28810^{\mathrm{T}}\right)$. A-E. Conidiophores and conidia. F-L. Conidia. Scale bars: $\mathrm{A}-\mathrm{D}=10 \mu \mathrm{m}$; L applies to $\mathrm{F}-\mathrm{L}=5 \mu \mathrm{m}$.

sometimes branched, cells walls thicker than those of vegetative hyphae, mononematous, macronematous, brown, paler towards apex, frequently swollen at the base, $70-230 \times 3-5.5 \mu \mathrm{m}$. Conidiogenous cells smooth-walled, terminal or intercalary, proliferating sympodially, pale brown to brown, subcylindrical to swollen, 4.5-11(-15) $\times 4-6 \mu \mathrm{m}$. Conidia smooth-walled, straight, ellipsoidal to obovoid, pale brown to brown, apical and basal cells frequently slightly paler than the middle cells, (2-)3(-4)-distoseptate, (12-)14.5-25 × 7-9.5 $\mu \mathrm{m}$; hila sometimes inconspicuous, flat, darkened, slightly thickened, 1.5-3 $\mu \mathrm{m}$ diam. Microconidiation, chlamydospores and sexual morph not observed.

Cultural characteristics - Colonies on PDA reaching 43-50 mm diam in $1 \mathrm{wk}$, with moderate to abundant aerial mycelium giving a cottony appearance; reverse olivaceous black; surface olivaceous grey with the cottony zones smoke grey to grey olivaceous.

Hosts - Brachiaria reptans, Chloris barbata, and Digitaria ciliaris.

Distribution - Thailand.

Material examined - THAILAND, Chiang Mai, Mae Wang, on Digitaria ciliaris, 9 July 2010, C. Senwanna (CBS H-23194, holotype; culture ex-type CPC 28800); Chiang Mai, San Sai, on Brachiaria reptans, 12 June 2010, C. Senwanna, culture CPC 28801; Chiang Mai, San 

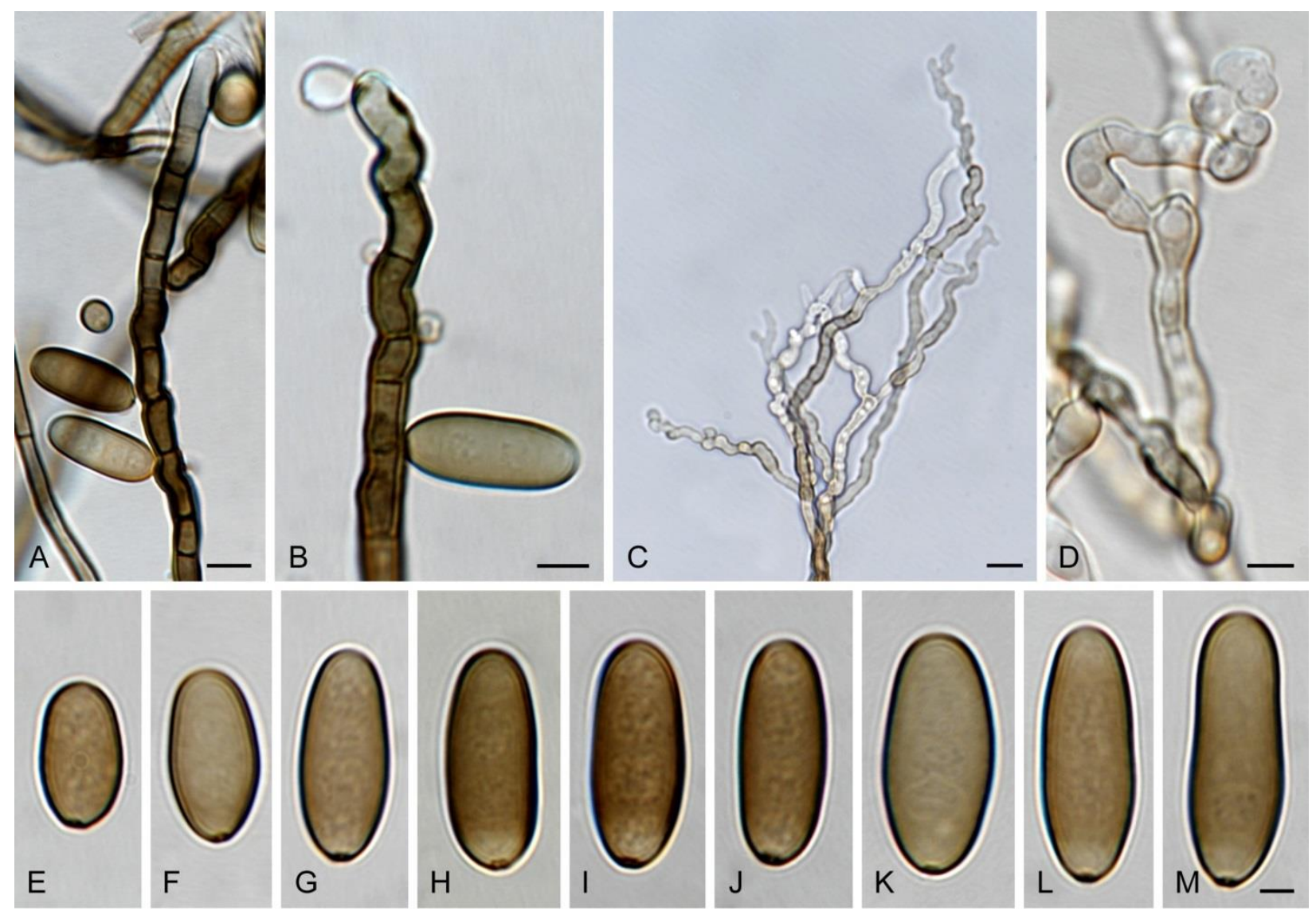

Figure 7 - Curvularia nodosa $\left(\mathrm{CPC} 28800^{\mathrm{T}}\right)$. A, B. Conidiophores and conidia. C, D. Knottedshaped hyphae. E-M. Conidia. Scale bars: A, B, D = 5 $\mu \mathrm{m} ; \mathrm{C}=10 \mu \mathrm{m} ; \mathrm{M}$ applies to $\mathrm{E}-\mathrm{M}=2.5$ $\mu \mathrm{m}$.

Kamphaeng, on Chloris barbata, 9 Sep. 2010, R. Cheewangkoon, culture CPC 28812.

Notes - Curvularia nodosa is closely related to $C$. dactyloctenii and $C$. hawaiiensis. Moreover, $C$. hawaiiensis has also been isolated from Thailand. However, it can be easily distinguished from both species by the production of knotted hyphae and shorter and less septate conidia [(2-)3(-4)-distoseptate and (12-)14.5-25 $\mu \mathrm{m}$ long in C. nodosa vs. 2-7-distoseptate and 12-37 $\mu \mathrm{m}$ long in $C$. hawaiiensis vs. 3-6-distoseptate and 32-55 $\mu \mathrm{m}$ long in $C$. dactyloctenii]. Furthermore, its conidiophores are longer than in $C$. hawaiiensis (70-230 $\mu \mathrm{m}$ in $C$. nodosa vs. up to $120 \mu \mathrm{m}$ in $C$. hawaiiensis).

Isolates belonging to $C$. nodosa were found on different hosts: Brachiaria reptans, Chloris barbata, and Digitaria ciliaris. Although $C$. hawaiiensis has been isolated from a wide host range, it has never been recorded from these hosts.

Curvularia pseudobrachyspora Y. Marín, Cheew. \& Crous, sp. nov.

Figs $8,10 \mathrm{~F}$

MycoBank: MB822085

Etymology - Named after its morphological resemblance to Curvularia brachyspora.

Leaf spots fusiform or elliptical, first brown-red, then brown with light tan centre. Asexual morphology on PDA: Hyphae hyaline to pale brown, branched, septate, 2-4(-5) $\mu \mathrm{m}$ diam. Conidiophores arising singly or in groups, septate, straight or flexuous, sometimes geniculate at 

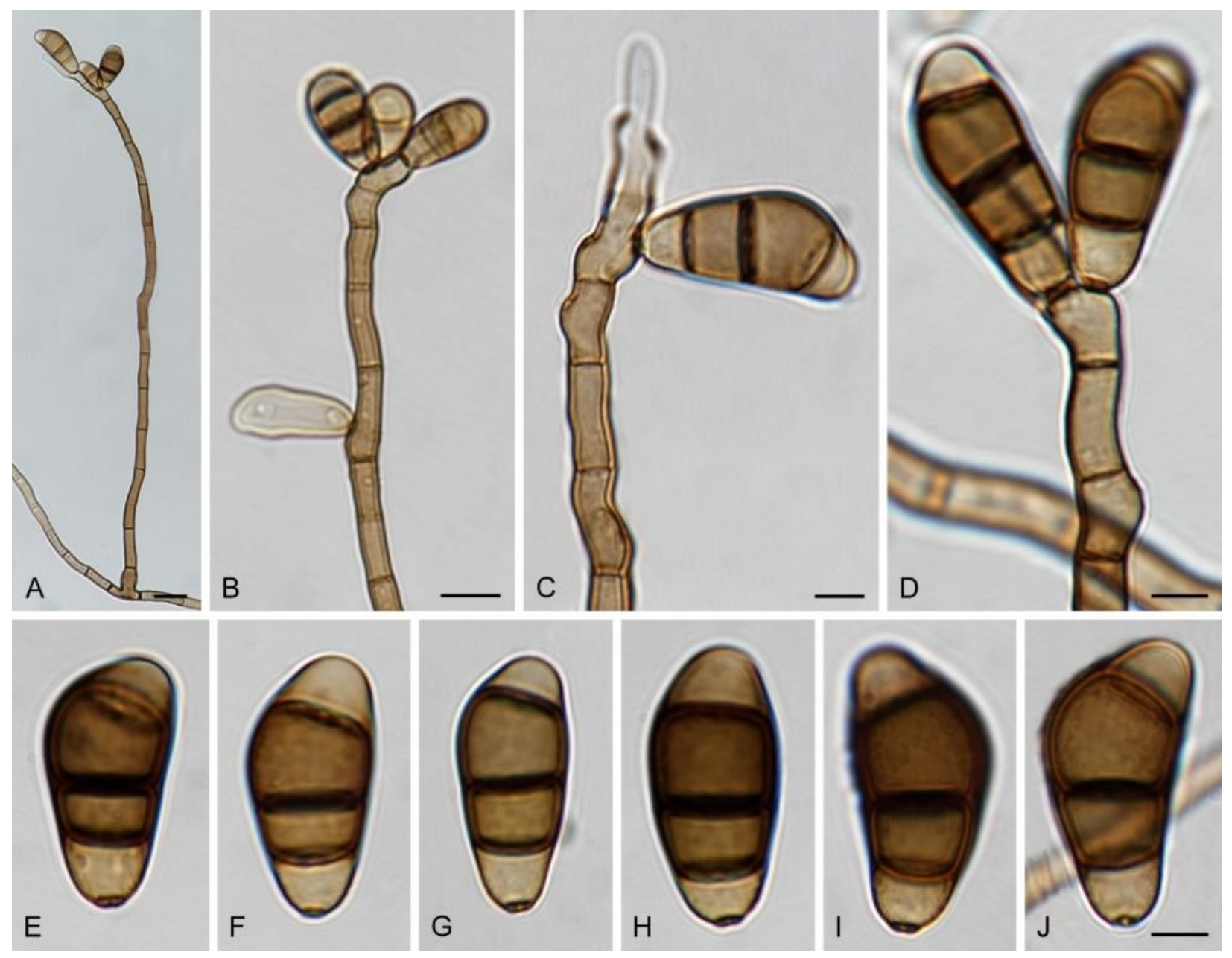

Figure 8 - Curvularia pseudobrachyspora $\left(\mathrm{CPC} 28808^{\mathrm{T}}\right)$. A-D. Conidiophores and conidia. EJ. Conidia. Scale bars: A, B $=10 \mu \mathrm{m} ; \mathrm{C}, \mathrm{D}$, J applies to $\mathrm{E}-\mathrm{J}=5 \mu \mathrm{m}$.

upper part, size of cells rarely decreasing towards apex, sometimes branched, cell walls thicker than those of vegetative hyphae, mononematous, semi- to macronematous, pale brown to brown, paler towards apex, sometimes swollen at the base, 110-420 $\times(2.5-) 3.5-6(-7) \mu \mathrm{m}$. Conidiogenous cells smooth-walled, terminal or intercalary, proliferating sympodially, pale brown to brown, subcylindrical to slightly swollen, 7-24(-26) $\times 4-6.5 \mu \mathrm{m}$. Conidia verruculose, mostly curved, ellipsoidal to obovoid, pale brown to brown, apical and basal cells paler than the middle cells, (2-)3-distoseptate, (16-)21.5-27(-28.5) × 8-14 $\mu \mathrm{m}$; hila protruding, darkened, thickened, 2-3(-4) $\mu \mathrm{m}$. Microconidiation, chlamydospores and sexual morph not observed.

Cultural characteristics - Colonies on PDA reaching 85-90 mm diam in $1 \mathrm{wk}$, with sparse aerial mycelium, margins fimbriate; surface with zones of pale mouse grey, and alternate zones grey olivaceous to olivaceous; reverse dark olivaceous with the margins transparent.

Host - Eleusine indica.

Distribution - Thailand.

Material examined - THAILAND, Chiang Mai, Jom Thong, on Eleusine indica, 23 May 2010, R. Cheewangkoon (CBS H-23195, holotype; culture ex-type CPC 28808). 
Notes - Curvularia pseudobrachyspora is related to C. brachyspora. Both species produce similar conidia with the same number of septa and dimensions. However, Curvularia pseudobrachyspora can be distinguished by its conidiophores being shorter than in $C$. brachyspora (up to $420 \mu \mathrm{m}$ long in $C$. pseudobrachyspora vs. up to $700 \mu \mathrm{m}$ long in $C$. brachyspora), as well as the absence of a sexual morph. Hitherto, Curvularia brachyspora has not been reported from Thailand, nor on Eleusine indica.

Curvularia variabilis Y. Marín, Senwanna \& Crous, sp. nov.

Figs 9, 10G

MycoBank: MB822086

Etymology - Named after the profound variability in conidial size.

Leaf spots oval, fusiform or irregular-shaped, brown or black with tan centre. Asexual morphology on PDA: Hyphae hyaline to pale brown, branched, septate, thin-walled, 1.5-5(-6.5) $\mu \mathrm{m}$ diam. Conidiophores arising singly or in groups, septate, straight or flexuous, sometimes geniculate in the upper part, size of cells do not decrease towards apex, sometimes branched, cells walls thicker than those of vegetative hyphae, mononematous, macronematous, pale brown to brown, paler towards apex, rarely slightly swollen at the base, 45-200(-240) $\times 2.5-6 \mu \mathrm{m}$. Conidiogenous cells smooth-walled to verruculose, terminal or intercalary, proliferating sympodially, pale brown to brown, subcylindrical to swollen, 4.5-10(-14.5) $\times 4-5.5 \mu \mathrm{m}$. Conidia verruculose, ellipsoidal to fusiform, pale brown, apical and basal cells paler than the middle cells, (0-)3-5(-6)-distoseptate, (18.5-)23-39 $\times 7-10(-11) \mu \mathrm{m}$; hila sometimes inconspicuous, flat to slightly protruding, darkened, thickened, 1.5-2.5(-3) $\mu \mathrm{m}$.

Cultural characteristics - Colonies on PDA reaching 75-90 $\mathrm{mm}$ diam in $1 \mathrm{wk}$, with abundant aerial mycelium giving a cottony appearance; surface olivaceous grey to olivaceous black; reverse olivaceous black.

Hosts - Chloris barbata, Digitaria ciliaris and Imperata cylindrica.

Distribution - Thailand.

Material examined - THAILAND, Chiang Mai, Samoeng, on Chloris barbata, 29 June 2014, C. Senwanna (CBS H-23196, holotype; culture ex-type CPC 28815); Chiang Mai, Doi Saket, on Digitaria ciliaris, 12 July 2010, R. Cheewangkoon, culture CPC 28813; Chiang Mai, Chiang Mai University, on Digitaria ciliaris, 14 July 2010, C. Senwanna, culture CPC 28814; Chiang Mai, Samoeng, on Imperata cylindrica, 29 June 2010, C. Senwanna, culture CPC 28816.

Notes - Curvularia variabilis is distinguished by its conidia, which are highly variabile in size. Curvularia variabilis is herein described from three different members of Poaceae, but all known isolates of this species originate from Thailand.

\section{Discussion}

Species of Bipolaris and Curvularia are important phytopathogens of members of Poaceae. The disease symptoms that these taxa cause include leaf spots, blight, melting out, root rot and foot root, among others (Sivanesan 1987, Manamgoda et al. 2014, Marin-Felix et al. 2017). Several isolates belonging to both genera were isolated from these disease symptoms of different members of Poaceae in Thailand (Fig. 10). Based on the phylogenetic analysis of ITS, gapdh and tefl sequences of these isolates, one new species of Bipolaris and five species of Curvularia were introduced. Bipolaris brachiariae was introduced in order to accommodate two isolates, one of them isolated from Brachiaria mutica and the other from an unknown member of Poaceae. 

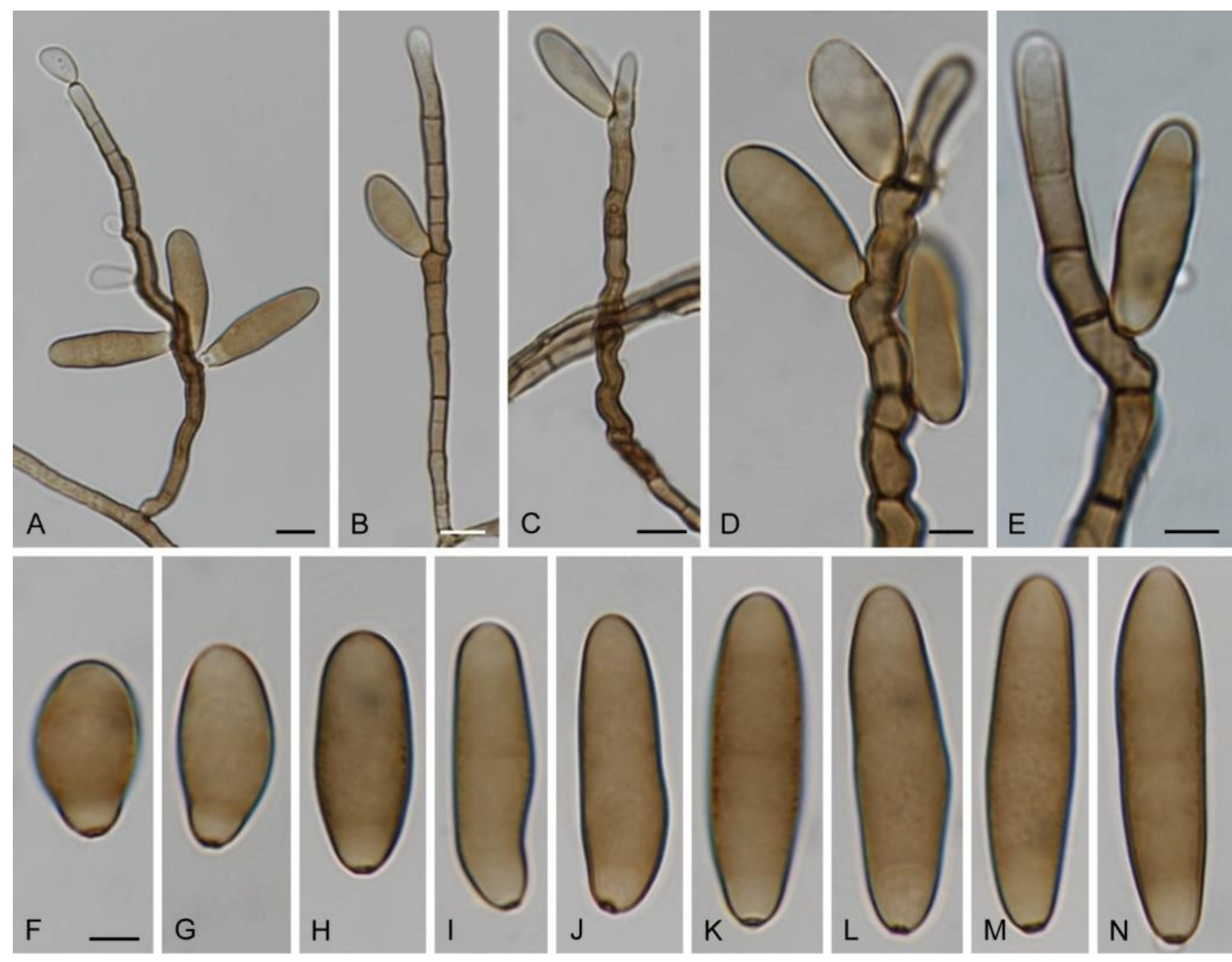

Figure 9 - Curvularia variabilis (CPC 28815 ${ }^{\mathrm{T}}$ ). A-E. Conidiophores and conidia. F-N. Conidia. Scale bars: $\mathrm{A}-\mathrm{C}=10 \mu \mathrm{m} ; \mathrm{D}, \mathrm{E}, \mathrm{F}$ applies to $\mathrm{F}-\mathrm{N}=5 \mu \mathrm{m}$.

This species is related to $B$. heliconiae, $B$. maydis and $B$. saccharicola, but produces shorter conidiophores and conidia than these species. Curvularia chiangmaiensis was described from Zea mays. It can be easily distinguished by its conidiophores that are up to $2000 \mu \mathrm{m}$ tall. Curvularia chiangmaiensis is closely related to C. dactyloctenicola, which is introduced in order to accommodate an isolate found on Dactyloctenium aegyptium. However, $C$. dactyloctenicola produces shorter condiophores and longer conidia than C. chiangmaiensis. Curvularia pseudobrachyspora was isolated from Eleusine indica, and is similar to C. brachyspora, but it is distinct in that it has shorter conidiophores and does not produce a sexual morph. Moreover, $C$. brachyspora has not been reported from Thailand or on E. indica (Farr \& Rossman 2017). Curvularia nodosa is known from three different hosts, namely from Brachiaria reptans, Chloris barbata and Digitaria ciliaris. This species is closely related to $C$. dactyloctenii and $C$. hawaiiensis. However, Curvularia nodosa can be easily distinguished by the production of knotted hyphae in culture. Furthermore, it differs from the other two related species in the size and septation of its conidia. The final species described in this study is Curvularia variabilis, which is characterized by its highly variable conidial dimensions. Several isolates were obtained belonging to $C$. variabilis, but all of them were collected in Thailand, where they occurred on 

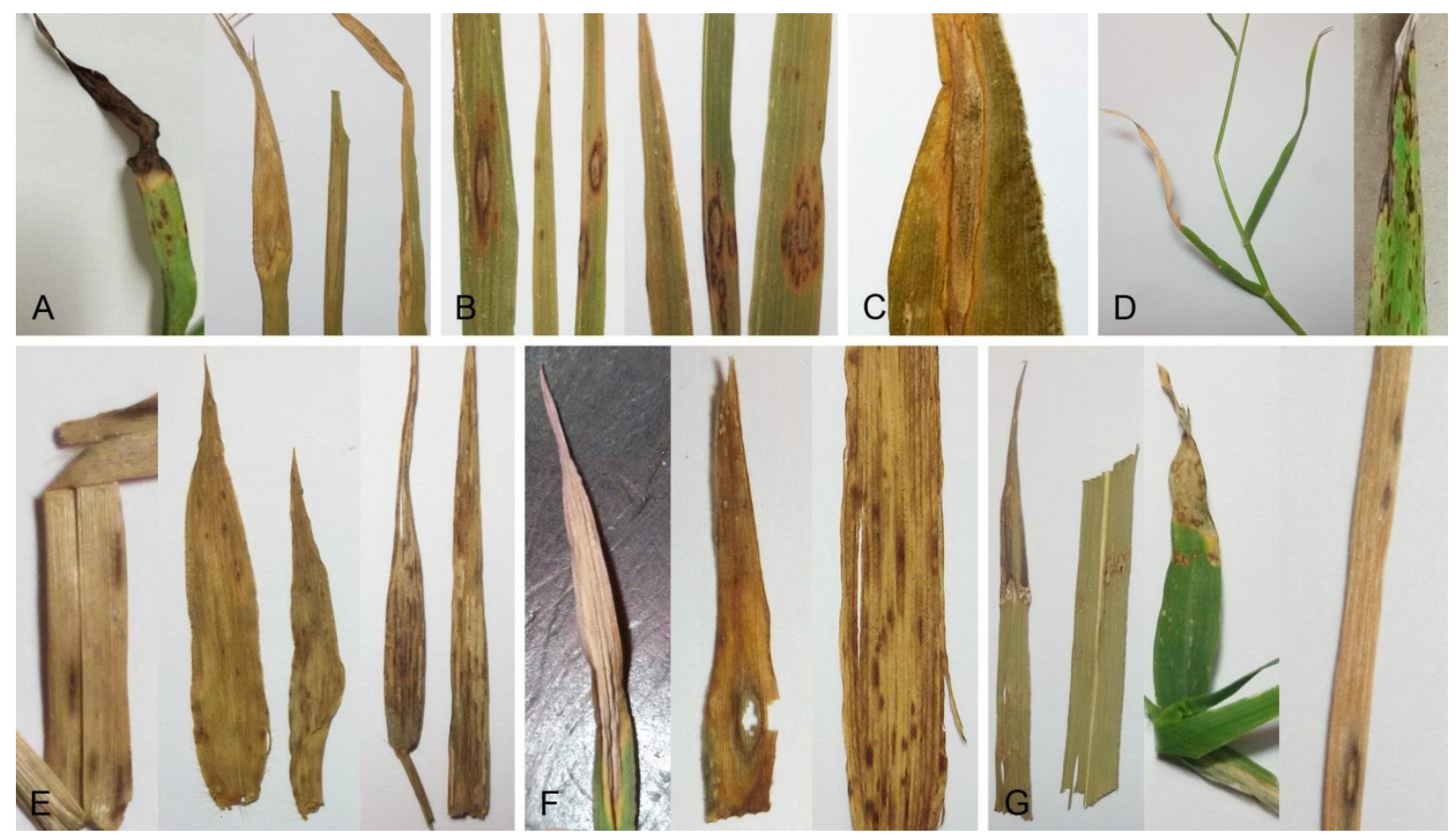

Figure 10 - Disease symptoms of members of the family Poaceae caused by species of Bipolaris and Curvularia. A. Bipolaris brachiariae on Brachiaria mutica. B. Bipolaris oryzae on Oryza sativa. C. Curvularia chiangmaiensis on Zea mays. D. Curvularia dactyloctenicola on Dactyloctenium aegyptium. E. Curvularia nodosa on Chloris barbata, Brachiaria reptans and Digitaria ciliaris. F. Curvularia pseudobrachyspora on Eleusine indica. G. Curvularia variabilis on Imperata cylindrica, D. ciliaris and C. barbata.

which is characterized by its highly variable conidial dimensions. Several isolates were obtained belonging to $C$. variabilis, but all of them were collected in Thailand, where they occurred on different hosts, namely Chloris barbata, Digitaria ciliaris and Imperata cylindrica.

Two isolates of Bipolaris were located in a well-supported subclade related to B. oryzae. Both isolates differ from the ex-neotype of $B$. oryzae in only one nucleotide. Therefore, although they did not form a well-supported clade, we consider that these belong to B. oryzae. Moreover, these were found on the same host, Oryza sativa, and B. oryzae is known to occur in Thailand (Manamgoda et al. 2014). Morphologically, these are similar to the ex-neotype, differing mainly in the size of the conidiophores and conidial septation. Therefore, we emended the description of $B$. oryzae to incorporate the observed morphology variation.

Several species included in Bipolaris and Curvularia were previously reported from Thailand. However, B. bicolor, B. setariae and B. yamadae represent new records. Furthermore, we also corroborated the presence of $B$. maydis in Thailand. In addition of these new distribution records, two Bipolaris and one Curvularia species were found on new hosts, namely B. bicolor and $C$. verruculosa on E. indica, and B. setariae on I. cylindrica. 


\section{Acknowledgements}

Yasmina Marin-Felix is grateful for the financial support received from the ViceChancellor's postdoctoral fellowship programme from University of Pretoria, South Africa. The collection trip in Thailand was supported by the Thailand Research Fund (MRG5580163).

\section{References}

Crous PW, Gams W, Stalpers JA, Robert V, Stegehuis G. 2004 - MycoBank: an online initiative to launch mycology into the 21st century. Studies in Mycology 50, 19-22.

Crous PW, Verkley GJM, Groenewald JZ, Samson RA (eds). 2009 - Fungal Biodiversity. CBS Laboratory Manual Series 1. Westerdijk Fungal Biodiversity Institute, Utrecht.

Ellis MB. 1971 - Dematiaceous Hyphomycetes. Commonwealth Mycological Institute, Kew.

Farr DF, Rossman AY. 2017 - Fungal Databases, U.S. National Fungus Collections, ARS, USDA. Retrieved June 9, 2017, from https://nt.ars-grin.gov/fungaldatabases/

Hernández-Restrepo M, Groenewald JZ, Elliott ML, Canning G et al. 2016 - Take-all or nothing. Studies in Mycology 83, 19-48.

Li JT, Fu JF, Yan XR, Li H, Zhou R. 2006 - Analysis of temporal dynamics of Curvularia leaf spot of maize (Curvularia lunata) epidemic and yield loss. Journal of Shenyang Agricultural University 37, 835.

Manamgoda DS, Cai L, McKenzie EHC, Crous PW et al. 2012 - A phylogenetic and taxonomic re-evaluation of the Bipolaris - Cochliobolus - Curvularia Complex. Fungal Diversity 56, 131-144.

Manamgoda DS, Rossman AY, Castlebury LA, Crous PW et al. 2014 - The genus Bipolaris. Studies in Mycology 79, 221-288.

Manamgoda DS, Rossman AY, Castlebury LA, Chukeatirote E, Hyde KD. 2015 - A taxonomic and phylogenetic re-appraisal of the genus Curvularia (Pleosporaceae): human and plant pathogens. Phytotaxa 212, 175-198.

Marin-Felix Y, Groenewald JZ, Cai L, Chen Q et al. 2017 - Genera of phytopathogenic fungi: GOPHY 1. Studies in Mycology 86, 99-216.

Ou SH. 1985 - Rice diseases, 2nd edn. CAB International, Wallingford.

Rayner RW. 1970 - A Mycological Colour Chart. Commonwealth Mycological Institute, Kew.

Scheffer RP. 1997 - The nature of disease in plants. Cambridge University Press, Cambridge.

Sivanesan A. 1987 - Graminicolous species of Bipolaris, Curvularia, Drechslera, Exserohilum and their teleomorphs. Mycological Papers 158, 1-261.

Tan YP, Crous PW, Shivas RG. 2016 - Eight novel Bipolaris species identified from John L. Alcorn's collections at the Queensland Plant Pathology Herbarium (BRIP). Mycological Progress 15, 1203-1214.

Ullstrup AJ. 1972 - The impacts of the southern corn leaf blight epidemics of 1970-1971. Annual Review of Phytopathology 10, 37-50.

White TJ, Bruns TD, Lee S, Taylor JW. 1990 - Amplification and direct sequencing of fungal ribosomal genes for phylogenetics. In: Innis MA, Gelfand DH, Sninsky JJ, White JW. PCR protocols: a guide to methods and applications. Academic Press, San Diego, 315-322. 